\title{
A METHOD FOR Colletotrichum graminicola INOCULATION IN MAIZE STALKS
}

\author{
DOUGLAS F. PARREIRA ${ }^{1}$, LAÉRCIO ZAMBOLIM ${ }^{1}$, RODRIGO V. DA COSTA ${ }^{2}$, \\ DAGMA D. DA SILVA², MARIELLE M. MARCONDES ${ }^{3}$, FABRÍCIO E. LANZA ${ }^{1}$, \\ WANIA S. NEVES ${ }^{4}$, JOSÉ E. F. FIGUEIREDO ${ }^{2}$, \\ ANDRÉ G.C. SOUZA ${ }^{1}$ e LUCIANO VIANA COTA ${ }^{2}$
}

\author{
${ }^{1}$ Universidade Federal de Viçosa (UFV), Viçosa, Minas Gerais, Brazil-douglas.parreira@ufv.br, \\ zambolim@ufv.br,falanza@bol.com.br,agcsouza@yahoo.com.br \\ ${ }^{2}$ Embrapa Milho e Sorgo, Sete Lagoas, Minas Gerais, Brazil - luciano.cota@embrapa.br, \\ rodrigo.veras@embrapa.br,dagma.silva@embrapa.br,jose.edson@embrapa.br, \\ ${ }^{3}$ Universidade do Meio Oeste, Guarapuava, Paraná,Brazil-m_lelinha@hotmail.com \\ ${ }^{4}$ Empresa de Pesquisa Agropecuária do Estado de Minas Gerais (EPAMIG), Viçosa, \\ Minas Gerais,Brazil-wanianeves@epamig.br
}

Revista Brasileira de Milho e Sorgo, v.15, n.1, p. 53-64, 2016

\begin{abstract}
Anthracnose stalk rot (ASR) disease caused by Colletotrichum graminicola can lead to major corn yield losses in Brazil. Studies on plant resistance and genetic variation in pathogen populations are required towards the development of ASR disease management strategies. However, the lack of adequate methods for C. graminicola inoculation in maize stalk has hindered these efforts. The main objective of the study was to develop a confident and feasible method for C. graminicola inoculation into maize stalk. Three inoculation methods were evaluated: TCMP (toothpick colonized by pathogen mycelium), TICS (toothpicks immersed in conidial suspension), and ICS (injection of conidial suspension). The effect of the internode position, the phenological stage, and the period of time required for maize reactions to ASR infection were also evaluated. The infection severity was assessed by a diagrammatic scale with six levels of severity from 0 (no necrotic spots) to 5 (100\% infection). The TICS was the best method, inoculation in the third internode and assessment of disease severity at tasselling stage (VT) 30 days after inoculation presented the more accurate results. The procedure was validated under field conditions.
\end{abstract}

Key words: Zea mays; stalk rot; anthracnose.

\section{MÉTODO PARA INOCULAÇÃO DE Colletotrichum graminicola EM COLMOS DE MILHO}

RESUMO - A podridão do colmo do milho causada por Colletotrichum graminicola causa perdas severas em lavouras de milho. Estudos com resistência de plantas e variabilidade genética do patógeno são necessários para o desenvolvimento de estratégias de manejo desta doença. Por outro lado, há ausência de uma metodologia adequada para a inoculação de C. graminicola em colmos. O objetivo principal do trabalho foi estabelecer uma metodologia confiável e prática para a inoculação de $C$. graminicola. Foram avaliados três métodos de inoculação em colmo: palitos de dente colonizados por micélio; palitos de dente imersos em suspensão de conídios; e injeção de suspensão de conídios. Nós também determinamos o efeito da posição do entrenó inoculado, o estádio fenológico para a inoculação e o período de tempo ideal após a inoculação para avaliar a severidade da doença. O método de palitos de dente imersos em suspensão de conídios inoculado no terceiro entrenó no estádio fenológico de pendoamento (VT) e avaliado aos 30 dias após a inoculação obteve o melhor resultado. A metodologia foi validada em plantas cultivadas em condições de campo.

Palavras-chave: Zea mays; podridão de colmo, antracnose. 
In recent years, the corn acreage in Brazil has increased significantly owing to the great importance of this cereal to Brazilian economy. In 2012-2013, the maize planted area in Brazil was estimated at 15.84 million hectares. The average productivity of $4991 \mathrm{~kg}$ $\mathrm{ha}^{-1}$ corresponded to 79.07 million tons, jointly the first and second planting seasons (CONAB, 2013). With the expansion of the Brazilian agricultural frontier, problems associated with the occurrence of diseases has increased, among corn diseases the anthracnose stalk rot has gained importance in the last years (Silva et al., 2015; Cota et al., 2012).

Corn anthracnose caused by Colletotrichum graminicola (Ces.) G.W. Wils (teleomorph Glomerella graminicola D.J. Politis) is an important disease worldwide (Bergstrom \& Nicholson, 1999). Although the disease can damage the entire plant, the most common symptoms observed in the field are the leaf spot and stalk rot. The anthracnose stalk rot (ASR) is omnipresent in Brazilian corn growing areas, being considered the most damaging disease for corn production (Silva et al., 2015; Costa et al., 2010). When Cota et al., (2012) looked at seven diseased maize hybrids, which were planted in two growing seasons, noted that the ASR significantly reduced the grain production.

The pathogen can survive in the soil as mycelium and conidia, on crop debris and on seeds, providing a fast inoculum accumulation in the corn fields (Bergstrom \& Nicholson, 1999). The pathogen colonizes the stalk tissues of vigorous plants prior the reproductive phase. In this scenario, direct damage is caused by the stem colonization in the vascular tissues reducing the absorption of water and nutrients. Consequently, the incomplete grain fill and lightweight mature kernels cause substantial yield losses. Moreover, successive plantation without tillage system and the use of susceptible genotypes contribute to the spread of the disease. During severe attacks, the premature death of plants is observed (Bergstrom \& Nicholson, 1999). The ASR can reduce ear weight and grain yield of maize by as much as $40 \%$, depending on genotype-environment interaction (Cota et al., 2012; Dodd, 1980; Keller et al., 1986; Perkins \& Hooker 1979; Smith, 1976). Costa et al. (2010) evaluated eighteen commercial hybrids during three years under natural infection, and reported that the premature death of maize plants was caused by $C$. graminicola infecting the entire stalk. Additionally, the stalk rot severity was correlated to the susceptibility of the eighteen genotypes and environmental conditions in each season (Costa et al., 2010). Therefore, the identification of resistant genotypes to anthracnose stalk rot, and the determination of $C$. graminicola variability are crucial to improve maize productivity in breeding programs. However, the lack of a reliable method for C. graminicola inoculation in maize plants, linking pathogen variability and plant resistance has hindered these efforts.

The main question addressed in this study was to establish a confident and feasible methodology for $C$. graminicola inoculation in maize stalk and to determine the most appropriate period of time after inoculation to evaluate the anthracnose stalk rot.

\section{Material and Methods}

The experiments were carried out from March 2009 to November 2010 at the National Research Centre for Maize and Sorghum, CNPMS/Embrapa, Sete Lagoas municipality in Minas Gerais State, Brazil.

Maize genotypes. Six maize genotypes were used in the experiments in a greenhouse: 2B710 (Dow Agroscience), 30F35 (Pioneer), Attack (Syngenta), 
BRS1001, BRS1010 (Embrapa), and DKB390 (Monsanto). The greenhouse tests were performed in clay pots 20 litters capacity (filled with loam, peat, and sand (4:4:1, vol/vol/vol)) with four seeds each. The pots were placed on counters in a greenhouse, at a temperature of approximately $25-28^{\circ} \mathrm{C}$. Approximately fifteen days after sowing, the thinning was accomplished leaving only one plant per pot.

The field experiments were performed with ten maize hybrids: 2B587, 2B710 (Dow Agroscience), 30P70, 30F80 (Pioneer), Attack, Tracktor (Syngenta), BRS1010, BRS1030, BRS1035 (Embrapa) and DKB390 (Monsanto).

Isolates and inoculums production. Ten monosporic isolates of $C$. graminicola: $6.08 \mathrm{M}$, $14.04 \mathrm{M}, 16.04 \mathrm{M}, 37.09 \mathrm{M}, 114.09 \mathrm{M}, 130.09 \mathrm{M}$, 132.09M, 150.09M, 152.09M, and 155.04M, from the Embrapa Maize and Sorghum Culture Collection of Multifunction Microorganisms and Phytopathogens were used in the experiments conducted in the greenhouse and in field trials. The isolate $16.04 \mathrm{M}$ was traditionally used at Embrapa Maize and Sorghum to test maize genotypes for anthracnose resistance; this isolate was deposited in Culture Collection of Phytopathogenic Fungi "Prof. Maria Menezes" with the number CMM 3012.

For inoculum preparation, each isolate was cultured on OMA medium (60 g oatmeal, $15 \mathrm{~g}$ agar, and $1000 \mathrm{~mL}$ deionised water) and incubated in a growth chamber at $28 \pm 2{ }^{\circ} \mathrm{C}$ under continuous fluorescent light. After five days, mycelia of each isolate were scarified for inducing sporulation. After three days, all conidia were scrapped from the culture and suspended with $0.02 \%$ tween in sterile deionised water. The final concentration was adjusted to $1.0 \mathrm{x}$ $10^{6}$ conidia $\mathrm{L}^{-1}$ according to Muimba-Kankolongo \& Bergstrom (1992).
Inoculation methods experiment. Three inoculation methods were evaluated: 1) TICS (toothpicks immersed in a conidial suspension) adapted from the Wernham "pipe cleaner" method (Christensen \& Wilcoxson, 1966); 2) TCMP (toothpick colonized by pathogen mycelium) adapted from Young (1943); 3) ICS (injection of conidial suspension) adapted from White \& Humy (1976). The corn plants were grown in clay pots 20 litters capacity with four seeds each. Approximately fifteen days after sowing, the thinning was accomplished leaving only one plant per pot. For TCMP method, sterilized toothpicks were placed in sterilized plates containing OMA and inoculated with the isolate 16.04M. After 7 days, the colonized toothpicks were collected and inserted into the stem soft of the plants growing in the greenhouse. For TICS, the sterilized toothpicks were imbibed in the conidial suspension at the time of inoculations. The toothpicks used in the experiments were sterilized twice by boiling (Crall, 1952), dried in an oven at $60^{\circ} \mathrm{C}$ and autoclaved at $121^{\circ} \mathrm{C}$ for $15 \mathrm{~min}$. In the first experiment performed in the greenhouse, the maize genotypes 2B710, 30F35, BRS1001 and DKB390 were submitted to the three different inoculation methods in order to evaluate the best method for $C$. graminicola inoculation. At the start of tasselling stage (VT), prior the inoculations, three leaf sheaths and leaves were excised from the plants to expose the internodes and the stems were superficially disinfected with $70 \%$ ethanol. For TICS and TCMP, the stems were perforated with a sterilized awl and the toothpick was inserted approximately $1 / 3$ of its length $(2.7 \mathrm{~cm})$. In TICS method a toothpick with approximately $0.03 \mathrm{~mL}$ of suspension (30,000 conidia) was applyed into the hole. For ICS method, the stems were injected with $0.5 \mathrm{~mL}$ of conidial suspension at $1 \times 10^{6}$ conidia. $\mathrm{mL}^{-1}$. 
Following the ICS procedure, the holes were sealed with silicone glue. Sterile toothpicks inserted into the third internodes were used as negative controls for methods TICS and TCMP, and the injection of sterilized water was the control for ICS method. The experiment was performed in a randomized complete block design with treatments arranged in a factorial scheme 4 (hybrids) x 3 (inoculation methods). The experiment consisted of six replications (two plants per replication) for each treatment totalizing 144 plants.

Evaluation periods experiment. The experiments were conducted under greenhouse for standardization and time estimation using TICS methodology; three hybrids (BRS1001, 2B710 and Attack) were inoculated with the isolate 16.04M. Sterilized toothpicks inserted into the third internodes were used as negative controls and the stalk colonization by the pathogen was evaluated at different intervals 5, 10, 15, 20, 25, and 30 days after inoculation (DAI). The experiment was performed by a randomized complete block design with treatments arranged in a factorial scheme 3 (hybrids) $\times 6$ (evaluation time) and ten replications (two plants per replication) for each treatment totalizing 360 plants.

Field trials. Ten maize hybrids were used in three experiments in the field designed for TICS standardization. In the field trials, the soil fertilization was performed by applying $30.0 \mathrm{Kg} \mathrm{ha}^{-1}$ of 8-2816 NPK topdressed, followed by two additional fertilizations with $100 \mathrm{~kg}$ of $\mathrm{N}$ (urea) 25 and 45 days after sowing. Field trials were planted in one-row plot $3 \mathrm{~m}$ long, spaced 0.8 meters apart, with five plants per meter. The first and second experiments were performed by a randomized complete block design with treatments arranged in a factorial design. The negative controls were the last plants in the end of each line, following the number of replications of each experiment and the evaluations were done at 30 DAI.

Phenological stages experiment. In the first field experiment, the isolate $16.04 \mathrm{M}$ was inoculated in the third internode position at three different phenological stages V7, V10, and VT (Ritchie et al., 1993). The experiment was performed by a randomized complete block design with treatments arranged in a factorial scheme 10 (hybrids) x 3 (phenological stages) and ten replications (two plants per replication).

Internode position experiment. In the second field experiment, the isolate $16.04 \mathrm{M}$ was inoculated in three internode positions, first, third and fifth internodes, at VT developmental stage. The experiment was performed by a randomized complete block design with treatments arranged in a factorial (10 hybrids x 3 internode positions) and ten replications (two plants per replication).

Final validation. In the third field experiment, ten isolates of C. graminicola (16.04M was included) were inoculated in the third internode of the corn plants at VT developmental stage. The experiment was performed by a randomized complete block design with treatments arranged in a factorial scheme (10 hybrids x 10 C. graminicola isolates) and 14 replications (one plant per replication).

Evaluation. At the end of all the experiments, the plants were harvested by cutting between the first internode and the first ear insertion and all the leaves and leaf sheaths were removed. For the evaluation, the harvested stalks were cut longitudinally and the extent of the injuries (necrosis) was assessed by a diagrammatic scale (Figure 1), adapted from Christensen \& Wilcoxson (1966). In order to improve the evaluation accuracy, the grading scale was 

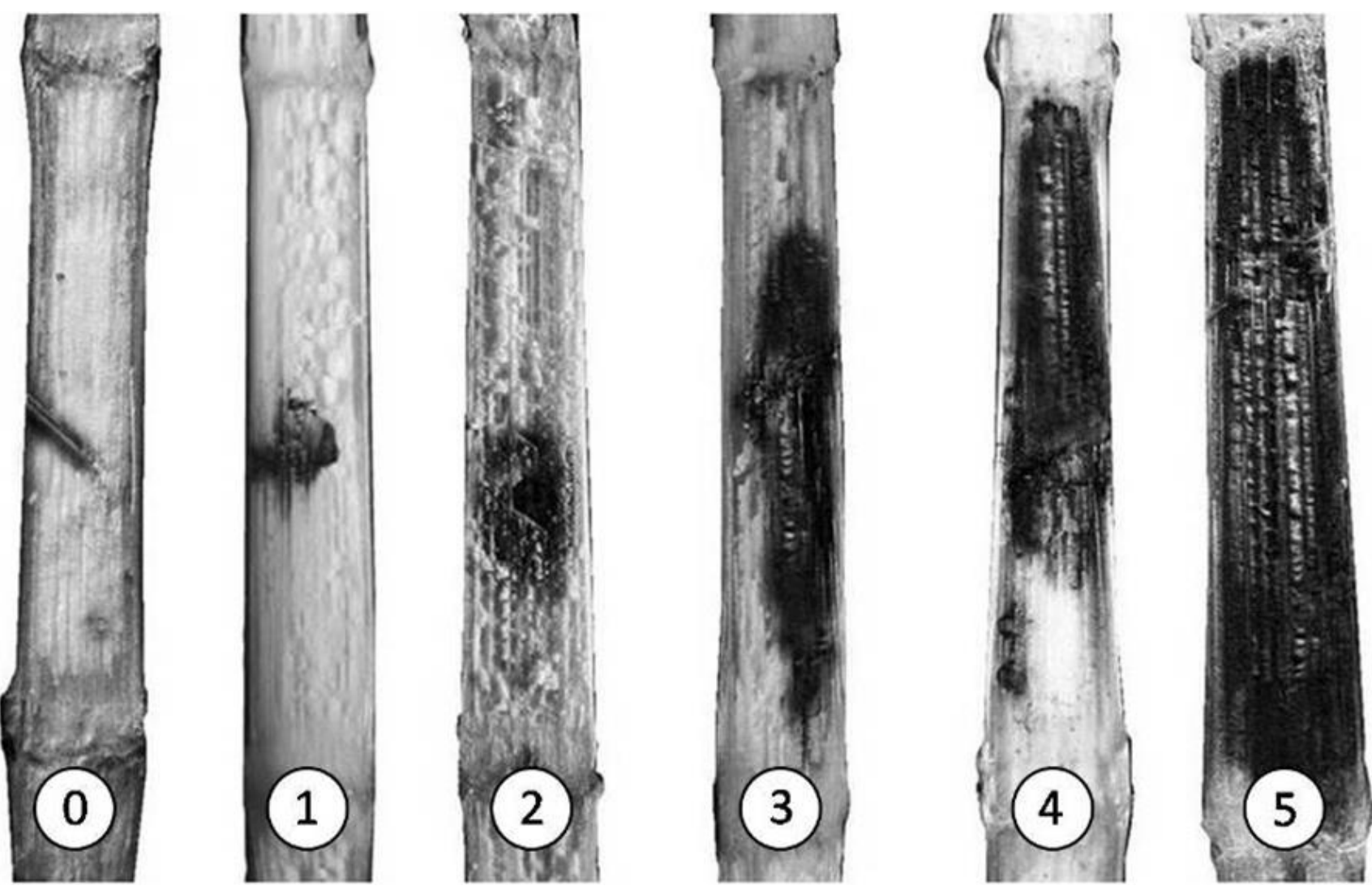

Figure 1. Rating scale used to evaluate stalk rot severity on the corn internodes. $0=0 \%$ necrotic tissue; $1=12.5 \%$ diseased tissue; $2=25 \%$ diseased tissue; $3=50 \%$ diseased tissue; $4=75 \%$ necrotic tissue, and $5=100 \%$ necrotic tissue.

subdivided into half-point values. The statistical analysis was performed with the SISVAR $®$-Version 5.3 software (Build 75; Ferreira, 2011).

\section{Results and Discussion}

Inoculation methods experiment. The three methods tested for $C$. graminicola inoculation in maize stems produced characteristic stalk rot lesions in plants growing in the greenhouse. The TICS method, followed by ICS and TCPM, showed the highest level of disease severity, and negative controls formed a group differing from the treatments (Table 1). The method TICS was the best for C. graminicola inoculation into maize internodes. This procedure showed several advantages such as low cost, faster execution and easy standardisation when compared to the other two methods tested (TCMP and ICS) (Table 1). Although TCMP and ICS were relatively efficient for C. graminicola inoculation, presented some problems not found in TICS method. For example, in the TCMP method a great loss of toothpicks rigidity was observed during their insertion in the stems, caused by fungal colonization.

According our found, Gásperi et al. (2003) and Keeling (1982) reported that TCMP method is useful to inoculate plant pathogens. They reported that TCMP is an efficient method to inoculate 
Table 1. Severity of anthracnose stalk rot on corn genotypes inoculated with the isolate $16.04 \mathrm{M}$ of $C$. graminicola, using three methods of inoculation.

\begin{tabular}{|c|c|c|c|c|c|c|c|}
\hline \multirow{2}{*}{ Genotypes } & \multicolumn{6}{|c|}{ Methods of inoculation } & \multirow{2}{*}{ Average } \\
\hline & $\mathrm{ICS}^{1}$ & $\mathrm{ICS}-\mathrm{NC}^{2}$ & $\mathrm{TCMP}^{3}$ & TCMP-NC & $\mathrm{TICS}^{4}$ & TICS-NC & \\
\hline 2B710 & $51.4 \mathrm{aB}$ & $2.1 \mathrm{aA}$ & $40.3 \mathrm{aB}$ & $4.9 \mathrm{aA}$ & $53.5 \mathrm{aB}$ & $2.1 \mathrm{aA}$ & $25.7 \mathrm{a}$ \\
\hline $30 \mathrm{~F} 35$ & $63.9 \mathrm{abB}$ & $17.8 \mathrm{aA}$ & $77.1 \mathrm{bcBC}$ & $16.7 \mathrm{aA}$ & $90.3 \mathrm{bC}$ & $2.1 \mathrm{aA}$ & $44.6 b$ \\
\hline BRS1010 & $80.3 \mathrm{bB}$ & $3.5 \mathrm{aA}$ & $80.3 \mathrm{cB}$ & $5.6 \mathrm{aA}$ & $82.6 \mathrm{bB}$ & $2.8 \mathrm{aA}$ & $42.5 b$ \\
\hline DKB390 & $80.6 \mathrm{bC}$ & $8.6 \mathrm{aA}$ & $60.4 \mathrm{bB}$ & $8.3 \mathrm{aA}$ & $73.3 \mathrm{bBC}$ & $3.5 \mathrm{aA}$ & $39.1 \mathrm{~b}$ \\
\hline Average & $69.0 \mathrm{BC}$ & $8.0 \mathrm{~A}$ & $64.5 \mathrm{~B}$ & $8.9 \mathrm{~A}$ & $74.9 \mathrm{C}$ & $2.6 \mathrm{~A}$ & \\
\hline
\end{tabular}

Injection of conidial suspension (ICS); ${ }^{2}$ negative control (NC); ${ }^{3}$ toothpick colonized by mycelium of the pathogen (TCMP); ${ }^{4}$ toothpick immersed in a conidial suspension (TICS); means followed by the same lower case letters on the column and capital letters on the lines do not differ significantly by the Tukey test (p-value $<0.0001$ )

soybean plants with Fusariumsolani (Mart.) Sacc and Diaporthe phaseolorum (Cooke and Ellis) Sacc in the greenhouse and field condition, but they did not describe loss of toothpicks rigidity. The ICS method had been reported as an efficient method for $C$. graminicola (Carson \& Hooker, 1981; Badu-Aprakuet et al., 1987; Reid \& Zhu 2005; Toman \& White 1993; White et al., 1987). Keller \& Bergstrom (1988) used the ICS method to determine the susceptible stages of corn plants to inoculate C. graminicola. MuimbaKankolongo \& Bergstrom (2011) used ICS method in field condition to define the best time after plant injury to inoculate $C$. graminicola, and they concluded that inoculation performed soon after injury is the most appropriate. However, in the present study the following problems were detected with the use of the ICS method for C. graminicola inoculation into corn plants: the amount of inoculum can vary depending on the applicator and equipment used; and it requires tedious cleaning of the equipment which may not be suitable for the inoculation of a large number of isolates. Thus, the process of cleaning the equipment becomes awkward, time-consuming and with risk of contamination.

Evaluation periods experiment. The best period for evaluations was $30 \mathrm{DAI}$; although, anthracnose stalk rot symptoms were observed with 10 DAI. Comparisons between cultivars BRS1001 (moderately resistant) and Attack (susceptible) showed that at 30 DAI the stems of both hybrids became widely colonized by the pathogen. In addition, the disease severity was very low and remained stagnated after the initial symptoms in 2B710, which is known by its high level of resistance (Figure 2). In this study, the highest level of disease severity was detected 30 DAI (Figure 2), whereas Muimba-Kankolongo\& Bergstrom (1992) standardized 21 DAI as the best time to evaluate the disease severity. However, in the present case, evaluation at 21 DAI would underestimate the disease severity.

Phenological stages experiment. The stalking rot was affected by the plant phenology of the ten maize genotypes, with the highest levels of severity observed in inoculations performed at the VT stage (Table 2). In addition, a better distinction of the hybrids resistance was obtained at the tasselling stage (VT). In the first and second phenological stages (V7 and V10), only the hybrid 2B710 showed significant difference in severity compared with the other 


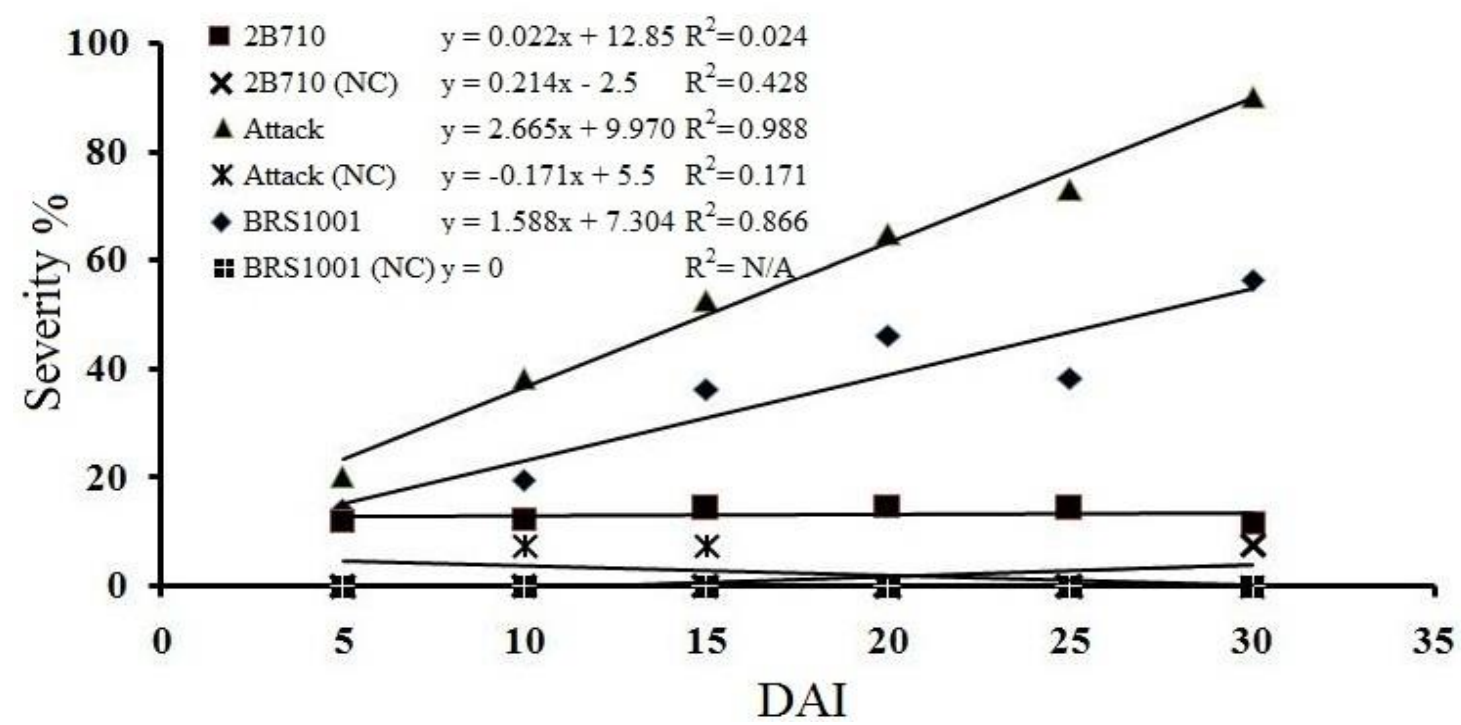

Figure 2. Linear regression of stalk rot disease severity caused by C. graminicola using three corn genotypes inoculated at greenhouse condition and negative control (NC) for each genotype, evaluated at 5, 10, 15, 20, 25 and 30 days after inoculation (DAI).

hybrids. In the VT stage, the level of disease severity was very low in 2B710, intermediate in BRS1010 and very high for the other eight hybrids. The highest severity mean $(81.43 \%)$ was observed on VT stage (Table 2), and this result was similar to the described by Keller \& Bergstron (1988) that found a significant increase in anthracnose stalk rot in plants inoculated on VT and R1 stages. Therefore, the VT stage was considered the most susceptible stage to anthracnose in this experiment.

Internode position experiment. The second field experiment evaluated the effect of the stalk internode position on disease severity, and the highest value was observed at the fifth internode for the ten hybrids tested. The third internode showed intermediate level of disease severity and the first internode showed the lowest severity level (Table 3). Evaluating the effect of internodes position (first, third or fifth) on inoculations, the results showed that the greatest disease severity was achieved by inoculations into the fifth internode (Table 3). However, physical characteristics of the stem in this part of the plant, such as thinness, make it prone to breakage during the leaf removal for inoculation. In some cases, the insertion of the ear coincides with the fifth internode that becomes unsuitable for inoculation. The results obtained for C. graminicola inoculations in the first internode were negligible, with low disease severity. In addition, operational difficulties were found during the inoculations and stalk sampling due to its proximity to soil. In the first internodes, adjoining the adventitious roots, the lesions were restricted to this internode, while in the two other internodes tested (third and fifth) inoculations caused adjacent up and down infections.

Final validation. In the third experiment, data of the field validation test showed that TICS method (inoculation at third internode in the VT stage and evaluated at $30 \mathrm{DAI}$ ) was effective for inoculation using different isolates of $C$. 
Table 2. Effect of phenological stages of maize on disease severity in ten corn genotypes inoculated with the isolate $16.04 \mathrm{M}$ of C. graminicola using TICS method.

\begin{tabular}{|c|c|c|c|c|c|c|c|}
\hline \multirow{3}{*}{ Genotypes } & \multicolumn{6}{|c|}{ Phenological Stages } & \multirow{3}{*}{ Averag } \\
\hline & & V7 NC & $\mathrm{V} 10$ & $\mathrm{U} 10 \mathrm{NC}$ & VT & UT NC & \\
\hline & & & & 0201 & & & \\
\hline 2B587 & $59.0 \mathrm{bC}$ & $10.6 \mathrm{aA}$ & $61.3 \mathrm{bC}$ & $9.2 \mathrm{aA}$ & $87.5 \mathrm{cC}$ & $8.3 \mathrm{aA}$ & $39.3 \mathrm{~B}$ \\
\hline 2B710 & $13.5 \mathrm{aA}$ & $9.2 \mathrm{aA}$ & $20.3 \mathrm{aA}$ & $7.2 \mathrm{aA}$ & $38.8 \mathrm{bA}$ & $9.1 \mathrm{aA}$ & $16.3 \mathrm{~A}$ \\
\hline $30 \mathrm{~F} 80$ & $46.0 \mathrm{bB}$ & $8.7 \mathrm{aA}$ & $57.5 \mathrm{bC}$ & $6.4 \mathrm{aA}$ & $96.2 \mathrm{bD}$ & $10.9 \mathrm{aA}$ & $37.6 \mathrm{~B}$ \\
\hline $30 \mathrm{P} 70$ & $57.5 \mathrm{bC}$ & $7.4 \mathrm{aA}$ & $40.0 \mathrm{bB}$ & $8.6 \mathrm{aA}$ & $80.0 \mathrm{cC}$ & $10.1 \mathrm{aA}$ & $33.9 \mathrm{~B}$ \\
\hline Attack & $43.3 \mathrm{bB}$ & $9.6 \mathrm{aA}$ & $46.5 \mathrm{bB}$ & $9.0 \mathrm{aA}$ & $88.8 \mathrm{cC}$ & $10.1 \mathrm{aA}$ & $34.5 \mathrm{~B}$ \\
\hline BRS 1035 & $58.5 \mathrm{bC}$ & $9.3 \mathrm{aA}$ & $44.8 \mathrm{bB}$ & $7.0 \mathrm{aA}$ & $91.3 \mathrm{cD}$ & $8.9 \mathrm{aA}$ & $36.6 \mathrm{~B}$ \\
\hline BRS1010 & $58.8 \mathrm{cC}$ & $10.3 \mathrm{aA}$ & $38.8 \mathrm{bB}$ & $9.7 \mathrm{aA}$ & $64.3 \mathrm{cB}$ & $6.3 \mathrm{aA}$ & $31.4 \mathrm{~B}$ \\
\hline BRS1030 & $60.0 \mathrm{bC}$ & $10.6 \mathrm{aA}$ & $49.5 \mathrm{bB}$ & $7.9 \mathrm{aA}$ & $86.3 \mathrm{cC}$ & $12.3 \mathrm{aA}$ & $37.8 \mathrm{~B}$ \\
\hline DKB390 & $65.0 \mathrm{bcC}$ & $8.7 \mathrm{aA}$ & $48.8 \mathrm{bB}$ & $9.8 \mathrm{aA}$ & $81.3 \mathrm{cC}$ & $10.2 \mathrm{aA}$ & $37.3 \mathrm{~B}$ \\
\hline Tracktor & $44.5 \mathrm{bB}$ & $10.7 \mathrm{aA}$ & $50.8 \mathrm{bB}$ & $9.1 \mathrm{aA}$ & $100.0 \mathrm{cD}$ & $8.2 \mathrm{aA}$ & $37.2 \mathrm{~B}$ \\
\hline Average & $50.6 \mathrm{~b}$ & $9.5 \mathrm{a}$ & $45.8 \mathrm{~b}$ & $8.4 \mathrm{a}$ & $81.4 \mathrm{c}$ & $9.5 \mathrm{a}$ & \\
\hline
\end{tabular}

${ }^{1}$ negative control (NC); means followed by the same lower case letters on the lines do not differ significantly by the Tukey test ( $\mathrm{p}$-value $<0.0001$ ); means followed by the same capital letters on the column do not differ significantly by the Scott-Knott test $(\mathrm{p}$-value $<0.0001)$.

Table 3. Effect of internodes positions on disease severity in ten corn genotypes inoculated with the isolate 16.04M of C. graminicola using TICS method.

\begin{tabular}{cccccccc}
\hline & \multicolumn{7}{c}{ Internode Position } \\
\cline { 2 - 6 } Genotypes & \multicolumn{7}{c}{ Average } \\
& first & first-NC & third & third-NC & fifth & fifth-NC \\
\hline 2 2B587 & $81.8 \mathrm{bD}$ & $11.2 \mathrm{aA}$ & $88.3 \mathrm{bcC}$ & $11.2 \mathrm{aA}$ & $95.8 \mathrm{dD}$ & $16.3 \mathrm{aA}$ & $50.8 \mathrm{C}$ \\
$2 \mathrm{~B} 710$ & $25.0 \mathrm{bA}$ & $10.5 \mathrm{aA}$ & $41.3 \mathrm{cA}$ & $12.1 \mathrm{abA}$ & $88.8 \mathrm{dC}$ & $9.8 \mathrm{aA}$ & $31.2 \mathrm{~A}$ \\
$30 \mathrm{~F} 80$ & $46.3 \mathrm{bB}$ & $9.0 \mathrm{aA}$ & $67.5 \mathrm{cB}$ & $14.6 \mathrm{aA}$ & $100.0 \mathrm{dD}$ & $13.2 \mathrm{aA}$ & $41.8 \mathrm{~B}$ \\
30P70 & $81.5 \mathrm{bD}$ & $12.3 \mathrm{aA}$ & $79.8 \mathrm{bC}$ & $12.8 \mathrm{aA}$ & $76.8 \mathrm{bB}$ & $10.7 \mathrm{aA}$ & $45.6 \mathrm{~B}$ \\
Attack & $62.8 \mathrm{bC}$ & $4.5 \mathrm{aA}$ & $86.0 \mathrm{cC}$ & $15.4 \mathrm{aA}$ & $76.8 \mathrm{cB}$ & $14.0 \mathrm{aA}$ & $43.6 \mathrm{~B}$ \\
BRS 1035 & $83.3 \mathrm{bD}$ & $10.2 \mathrm{aA}$ & $94.5 \mathrm{cdD}$ & $13.7 \mathrm{aA}$ & $100.0 \mathrm{cD}$ & $15.8 \mathrm{aA}$ & $52.9 \mathrm{C}$ \\
BRS1010 & $78.3 \mathrm{bD}$ & $12.0 \mathrm{aA}$ & $91.7 \mathrm{bcD}$ & $12.8 \mathrm{aA}$ & $98 . \mathrm{cD}$ & $18.7 \mathrm{aA}$ & $52.0 \mathrm{C}$ \\
BRS1030 & $67.0 \mathrm{bC}$ & $9.0 \mathrm{aA}$ & $86.5 \mathrm{cC}$ & $12.2 \mathrm{aA}$ & $62.3 \mathrm{bA}$ & $9.8 \mathrm{aA}$ & $41.1 \mathrm{~B}$ \\
DKB390 & $85.8 \mathrm{bD}$ & $11.7 \mathrm{aA}$ & $95.5 \mathrm{bD}$ & $10.0 \mathrm{aA}$ & $85.3 \mathrm{bC}$ & $17.2 \mathrm{aA}$ & $50.9 \mathrm{C}$ \\
Tracktor & $44.0 \mathrm{bB}$ & $6.6 \mathrm{aA}$ & $83.3 \mathrm{cC}$ & $13.7 \mathrm{aA}$ & $93.8 \mathrm{cD}$ & $12.9 \mathrm{aA}$ & $42.4 \mathrm{~B}$ \\
\hline Average & $65.6 \mathrm{~b}$ & $9.7 \mathrm{a}$ & $81.4 \mathrm{c}$ & $12.9 \mathrm{a}$ & $88.0 \mathrm{~d}$ & $13.9 \mathrm{a}$ & \\
\hline
\end{tabular}

${ }^{1}$ negative control (NC); means followed by the same lower case letters on the lines do not differ significantly by the Tukey test (p-value $<0.0001$ ), means followed by the same capital letters on the column do not differ significantly by the Scott-Knott test (p-value $<0.0001)$. 


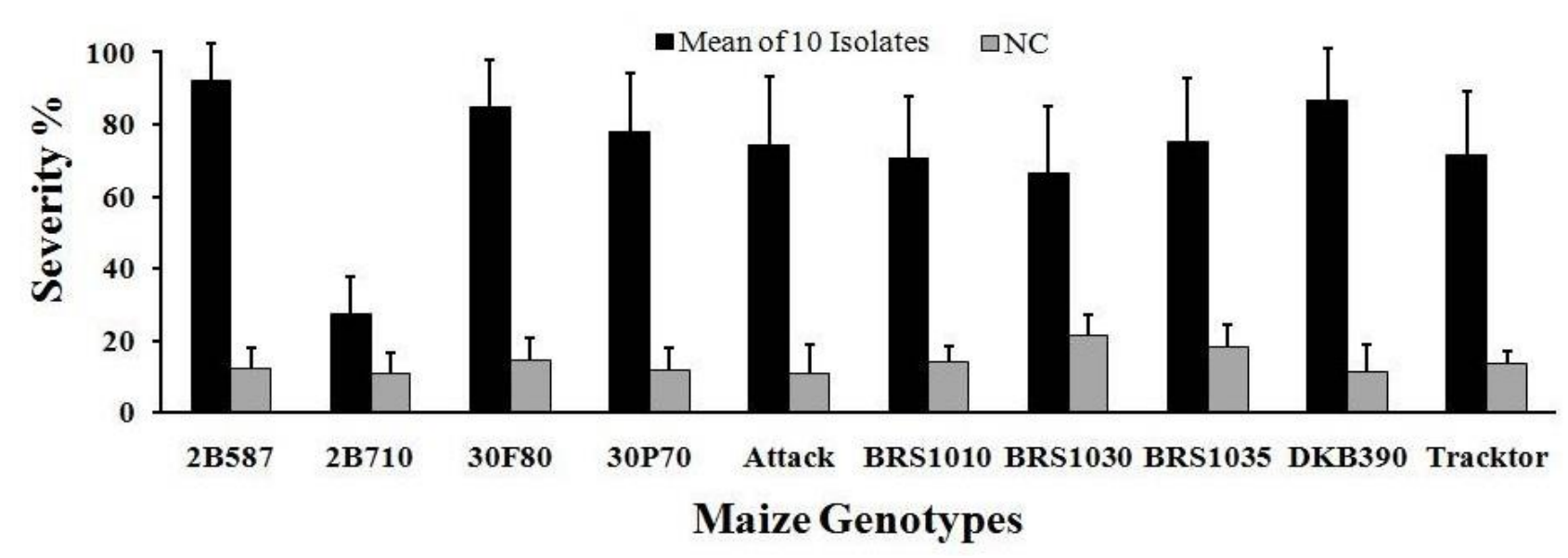

Figure 3. Severity means (\%) of stalk rot in ten corn cultivars inoculated in the field with ten C. graminicola isolates: 6.08M, 14.04M, 16.04M, 37.09M, 114.09M, 130.09M, 132.09M, 150.09M, 152.09M, and 155.04M. Negative control (NC). Bars represent the average standard deviation.

graminicola (Figure 3).

Although the inoculation of $C$. graminicola was accomplished after the hole drilled in the stem, there are reports that show that $C$. graminicola could infect stems with or without injuries (Venard \& Vaillancourt 2007a, 2007b). The anthracnose stalk epidemics has been associated in part with the increase of the population of European corn borer Ostrinia nubilalis (Hübner) which causes perforations in stalk, facilitating access of the fungus C. graminicola to internal plant tissues (MuimbaKankolongo \& Bergstrom, 1990, 1992; Keller et al., 1986). In Brazil the sugar cane borer Diatraea saccharalis (Fabricius) commonly occurs in maize plantings (Cruz, 2007) causing the same type of interaction that European corn borer. Even if we try to mimic what happens in early inoculations in plants at field does not necessarily guarantee that the isolate will colonize the stems because the development of the disease in stalk increases when the corn plant begins to mobilize its reserves for grain filling in the reproductive phase (Keller \& Bergstrom 1988).
Using the TICS methodology we facilitated access of the fungus to the stalk tissues by the hole drilled in the stem and approaching to the favorable conditions in the field with the presence of corn borer. Currently, the injection of spores in the first or second internodes, just above adventitious roots, is the most common method for $C$. graminicola inoculation in the field (Keller \& Bergstrom 1988; Muimba-Kankolongo \& Bergstrom 2011; Nyhus et al., 1989), in these cases inoculations are made with one or few isolates. The combination of TICS in the third internodes of plants at the VT stage and the disease severity assessed 30 DAI is a practical and easy method for C. graminicola inoculation under field conditions. Using this method, all the isolates infected the inoculated stalks, and no contamination was found in the controls, thus enabling the use of this method for quickly assess resistance to anthracnose stalk rot (ASR) in maize for disease management strategies. Therefore, we expect that the methodology described in this study will be useful in corn breeding programs for disease resistance and for studies on pathogen variability. Five races 
of C. graminicola associated with the anthracnose leaf blight of maize were detected in Brazil (Costa et al., 2014), one of five races represent more than $80 \%$ of 190 isolates used in work, reinforcing the importance of a large number of isolates needed to be inoculated in this kind of study. Considering that only one gene for resistance at the anthracnose stalk rot was described (Broglie et al., 2006), there are the possibility to separate $C$. graminicola isolates in at least two distinct races; therefore the methodology described in this work could be useful.

\section{Conclusion}

The methodology of toothpicks immersed in a conidial suspension combined with inoculation in the third internodes of plants at the VT stage and the disease severity assessed 30 days after inoculation is a practical and easy method for C. graminicola inoculation under greenhouse and field conditions.

\section{Acknowledgments}

The authors would thanks Dr Simona Florea for english review; Conselho Nacional de Desenvolvimento Cientifico e Tecnológico (CNPq) for the first author research grant; Coordenação de Aperfeiçoamento de Nível Superior, CAPES; Embrapa Milho e Sorgo, and Fundação de Amparo à Pesquisa do Estado de Minas Gerais, FAPEMIG.

\section{References}

BADU-APRAKU, B.; GRACEN, V. E.; BERGSTRON, G. C. A major gene for resistance to anthracnose stalk rot in maize. Phytopathology, Saint Paul, v. 77, p. 957-959, 1987.
BERGSTROM, G. C.; NICHOLSON, R. L. The biology of corn anthracnose: knowledge to exploit for improved management. Plant Disease, Saint Paul, v. 83, p. 596-608, 1999. DOI: 10.1094/PDIS.1999.83.7.596.

BROGLIE, K. E.; BUTLER, K. H.; BURTRUILLE, M. G.; CONCEIÇÃO,A. da S.; FREY, T. J.; HAWK, J.A.; JAQUET, J. S.; JONES, E. S.; MULTANI, D. S.; WOLTERS, P. J. C. C. Polynucleotides and methods for making plants resistant to fungal pathogens. U.S. 20090035765A1.2009. WO 2006107931 A2. 04 abr. 2006, 12 out. 2006.

CARSON, M. L.; HOOKER, A. L. Inheritance of resistance to stalk rot of corn caused by Colletotrichum graminicola. Phytopathology, Saint Paul, v. 71, p. 1190-1196, 1981. DOI: 10.1094/Phyto-71-1190.

CHRISTENSEN, J. J.; WILCOXSON, R. D. Stalk rot of corn. Saint Paul: American Phytopathological Society, 1966. (Monograph, 3).

CONAB. Companhia Nacional de Abastecimento. Acompanhamento de safra brasileira: grãos, décimo levantamento, julho 2013. Brasília, DF, 2013. Available at: $\quad<$ http://www.conab.gov.br/OlalaCMS/uploads/ arquivos/130709090453boletimgraosjunho2013.pdf $>$. Accessed on: 30 July 2013.

COSTA, R. V. da; COTA, L. V.; SILVA, D. D. da; PARREIRA, D. F.; CASELA, C. R.; LANDAU, E. C.; FIGUEIREDO, J. E. F. Races of Colletotrichum graminicola pathogenic to maize in Brazil. Crop Protection, Guildford, v. 56, p. 44-49, 2014. DOI: 10.1016/j.cropro.2013.10.005.

COSTA, R. V.; SILVA, D. D.; COTA, L. V.; PARREIRA, D. F.; FERREIRA, A. S.; CASELA, C. R. Incidência de Colletotrichum graminicola em colmos de genótipos de milho. Summa Phytopathologica, Botucatu, v. 36, n. 2, p. 122-128, 2010. DOI: $10.1590 / \mathrm{S} 0100-54052010000200003$.

COTA, L. V.; COSTA, R. V. da; SILVA, D. D.; CASELA, 
C. R.; PARREIRA, D. F. Quantification of yield losses due to anthracnose stalk rot on corn in Brazilian conditions. JournalofPhytopathology, Berlin,v. 160,p. 680-684, 2012. DOI: $10.1111 /$ jph. 12008 .

CRALL, J. M. A toothpick tip method of inoculation. Phytopathology, Saint Paul, v. 42, p. 5-6, 1952.

CRUZ,I.ABroca da cana-de-açúcar,Diatraea saccharalis, em milho, no Brasil. Sete Lagoas: Embrapa Milho e Sorgo, 2007. 12 p. (Embrapa Milho e Sorgo. Circular Técnica, 90).

DODD, J. L. Grain sink size and predisposition of Zea mays to stalk rot. Phytopathology, Saint Paul, v. 70, p. 534-535, 1980.

FERREIRA, D. F. Sisvar: a computer statistical analysis system. Ciência e Agrotecnologia, Lavras, v. 6, p. 1039$1042,2011$.

GÁSPERI, A. C.; PRESTES, A. M.; COSTAMILAN, L. $\mathrm{M}$. Reação de cultivares de soja à podridão vermelha da raiz causada por Fusariumsolani f. sp. glycines. Fitopatologia Brasileira, Brasília, DF, v. 28, p. 544-547, 2003. DOI: 10.1590/S0100-41582003000500013.

KEELING,B.L.Aseedlingtest forresistance to soybeanstem canker caused by Diaporthe phaseolorum var. caulivora. Phytopathology, Saint Paul, v. 72, p. 807-809, 1982.

KELLER, N. P.; BERGSTRON, G. C. Developmental predisposition of maize to anthracnose stalk rot. Plant Disease, Saint Paul, v. 72, p. 977-980, 1988.

KELlER, N. P.; BERGSTRON, G. C.; CARRUTHERS, R. I. Potential yield reductions in maize associated with an anthracnose/european corn borer pest complex in New York. Phytopathology, Saint Paul, v. 76, p. 586-589, 1986.

MUIMBA-KANKOLONGO, A.; BERGSTROM, G. C. Reduced anthracnose stalk rot in resistant maize is associated with restricted development of Colletotrichum graminicola in pith tissues. Journal of Phytopathology, Berlin, v. 159, p. 329-341, 2011. DOI: $10.1111 /$ j.1439-0434.2010.01766.x.
MUIMBA-KANKOLONGO, A.; BERGSTROM, G. C. Transitory wound predisposition of maize to anthracnose stalk rot. Canadian Journal of Plant Pathology, Ottawa, v. 12, p. 1-10, 1990. DOI: $10.1080 / 07060669009501035$.

MUIMBA-KANKOLONGO, A.; BERGSTROM, G. C. Wound predisposition of maize to anthracnose stalk rot as affected by internode position and inoculums concentration of Colletotrichum graminicola. Plant Disease, Saint Paul, v. 76, p. 188-195, 1992. DOI: $10.1094 /$ PD-76-0188.

NYHUS, K. A.; RUSSELL, W. A.; GUTHRIE, W. D.; MARTINSON, C. A. Reaction of two maize synthetics to anthracnose stalk rot and northern corn leaf blight following recurrent selection for resistance to Diplodia stalk rot and European corn borer. Phytopathology, Saint Paul, v. 79, p. 166-169, 1989. DOI: 10.1094/Phyto-79-166.

PERKINS, J. M.; HOOKER, A. L. The effects of anthracnose stalk rot on corn yields in Illinois. Plant Disease Reporter, Washington, v. 63, p. 26-30, 1979.

REID, L. M.; ZHU, X. Screening corn for resistance to common diseases in Canada. Ottawa: Agriculture and Agri-Food Canada, 2005. Available at: <http:// publications.gc.ca/collections/Collection/A42-103-2005E. pdf $>$. Accessed on: 24 July 2013.

RITCHIE, S. W.; HANWAY, J. J.; BENSON, G. O. How a corn plant develops. Ames: Iowa State University of Science and Technology, 1993. SP-48. Available at: $<$ http://www.extension.iastate.edu/hancock/info/corn. htm>. Accessed on: 12 June 2013.

SILVA, D. D.; COTA, L. V.; COSTA, R. V. Doenças. In: CRUZ, J. C. (Ed.). Cultivo do milho. 9. ed. Sete Lagoas: Embrapa Milho e Sorgo, 2015. (Embrapa Milho e Sorgo. Sistemas de produção, 1). Available at: <https://www. spo.cnptia.embrapa.br/conteudo?p_p_id=conteudoportlet_ WAR_sistemasdeproducaolf6_1ga1ceportlet\&p_p_ lifecycle $=0 \& p \_p \_s t a t e=$ normal\&p_p_mode $=$ view $\& p \_p \_$ col_id=column-1\&p_p_col_count=1\&p_r_p_-76293187_ 
sistemaProducaoId=7905\&p_r_p_-996514994_ topicoId=8666>. Accessed on: 24 Nov. 2015.

SMITH, D. R. Yield reduction in dent corn caused by Colletotrichum graminicola. Plant Disease Reporter, Washington, v. 60, p. 967-970, 1976.

TOMAN, J. J.; WHITE D. G. Inheritance of resistance to anthracnose stalk rot of corn. Phytopathology, Saint Paul, v. 83, p. 981-986, 1993. DOI: 10.1094/Phyto-83-981.

VENARD, C.; VAILLANCOURT, L. Colonization of fiber cells by Colletotrichum graminicola in wounded maize stalks. Phytopathology, Saint Paul, v. 97, p. 438-447, 2007a. DOI: 10.1094/PHYTO-97-4-0438.

VENARD, C.; VAILLANCOURT, L. Penetration and colonization of unwounded maize tissues by the maize anthracnose pathogen Colletotrichum graminicola and the related nonpathogen C. sublineolum. Mycologia, New York, v. 99, p. 368-377, $2007 \mathrm{~b}$. DOI: 10.3852/mycologia.99.3.368.
WHITE, D. G.; HUMY, C. Methods for inoculation of corn stalks with Colletotrichum graminicola. Plant Disease Reporter, Washington, v. 60, p. 898-899, 1976.

WHITE, D. G.; YANEY, J.; ANDERSON, B. Variation in pathogenicity, virulence and aggressiveness of Colletotrichum graminicola on corn. Phytopathology, Saint Paul, v. 77, p. 999-1001, 1987. DOI: 10.1094/Phyto-77-999.

YOUNG, H. C. J. The toothpick method of inoculating corn for ear and stalk rot. Phytopathology, Saint Paul, v. 33, p. 16, 1943. 